\title{
The Effects of Financial Restatement and Corporate Governance Mechanisms on Firm Value
}

\author{
Suhaily Hasnan, Norazzie Md Zin, Alfiatul Rohmah Mohamed Hussain
}

\begin{abstract}
This study examines the relationship between financial restatement and firm value in Malaysian public listed firms. In addition, it assesses the moderating effects provided by corporate governance mechanisms on the relationship of financial restatements and firm value. The study covers the period 2009-2015 and involves 142 public listed companies in Bursa Malaysia with financial restatements. The findings reveal that financial restatements do adversely impact firm value and that financial restatements negatively and significantly affect firm value. In terms of moderating variables, we find that the interaction between financial restatement and family ownership is negatively associated with firm value. In addition, this study also finds that the interaction between financial restatement and institutional ownership is positively and significantly associated with firm value. In conclusion, in the Malaysian context, this study establishes that financial restatement has a negative impact on firm value.

Index Terms: Corporate governance, firm value, restatement
\end{abstract}

\section{INTRODUCTION}

Financial restatement (FR) issues continue to be unresolved as the number of restatements continues to grow from year to year following the high profile cases in the recent past that have left investors with substantial losses. In the United States (US), the Securities and Exchange Commission (SEC) (2002) regards financial restatement as an important reason for the loss of investors' confidence, and former SEC chairman [50] stated that innumerable investors experienced loss of billions of dollars due to FR. Reference [47:pp. 1] states that "A financial statement restatement occurs when a company, either voluntarily or prompted by auditors or regulators, revises public financial information that was previously reported." FR reflects an acknowledgement that the financial statement, as originally reported to the public and lodged with the SEC, was not in accordance with GAAP [58]. Reference [11] argued that restatement clearly signals that the firm's prior financial statement was not credible and was of relatively lower "quality". They further argued that investors rely on the financial statement for forecasting a firm's future profitability, and that accounting information helps to reduce information asymmetries between management and investors. FR leads to both a decrease in the expected future earnings and an increase in the cost of equity

Revised Manuscript Received on September 22, 2019.

Suhaily Hasnan, Faculty of Accountancy, Universiti Teknologi MARA, Shah Alam (UiTM), Malaysia.

Norazzie Md Zin, Faculty of Accountancy, UiTM, Shah Alam, Malaysia.

Alfiatul Rohmah Mohamed Hussain, Faculty of Accountancy, UiTM, Shah Alam, Malaysia. capital [41] as well as the negative market reaction triggered by the announcement of restatement [58]. A developed nation like Australia also experiences negative market value and an average abnormal return of about 9 per cent over a 2-day announcement window due to FR [10].

Corporate governance is defined by the Malaysian SC (2012) as "The process and structure used to direct and manage the business and affairs of the company towards enhancing business prosperity and corporate accountability with the ultimate objective of realising long-term shareholder value, whilst taking into account the interests of other stakeholders." Corporate governance also plays a vital role in determining firm value. Reference [15] documented that better governed firms are relatively more profitable, more valuable, and pay out more cash to their shareholders. Reference [42] found that weak corporate governance is related to low corporate performance, investment and financing pattern. Reference [61] found that firms that have restated previously released financial reports, implement subsequent changes in internal governance in an effort to correct the underlying problems that contributed to the need for restatement in the first place. This evidence provides a starting point to further investigate the impact of financial restatement on firm value and whether corporate governance could mitigate the possibility of the negative impact on firm value in Malaysian firms.

Despite the extensive research on the impact of FR in the developed countries, the question of how the restatement of past accounting information affects the Malaysian capital market and the issue of corporate governance in mitigating the negative impact of FR on firm value has received relatively little attention. In the period 2002-2005, 32 financial statements of Malaysian companies were restated, especially pertaining to financial information concerning cost and expense [9]. Although the number shown is significantly low, it needs to be addressed since it can affect investors' confidence [9]. Hence, this study examines the effects of the Malaysian Code on Corporate Governance on the nature of financial restatement in Malaysia, and whether corporate governance characteristics are associated with financial restatement. In view of the fact that there is a lack of studies on FR in Malaysia, this study investigates the long-term effect of FR on firm value within the Malaysian environment.

The organization of the paper is as follows. Section 2 describes hypotheses development, followed by a section on research design. The subsequent section 
discusses the results of the study, and the paper is concluded in the final section.

\section{HYPOTHESES DEVELOPMENT}

This paper constructs five hypotheses related to financial restatement and firm value in Malaysian public listed firms.

\section{A. Financial Restatement and Firm Value}

Studies on Financial Restatement (FR) have shown that it has various financial and non-financial impacts. These have resulted in increased awareness from all market players towards the issue of FR. Reference [24] determined that income-decreasing earnings restatement that was the result of aggressive accounting policies would result in higher $\mathrm{CFO}$ turnover rates, and lower bonus compensation, especially when the firm is the target of a restatement-related class-action securities lawsuit. Similarly, restating firms experience a turnover of at least one top manager within 24 months of the restatement compared to 35 per cent among age, size and industry matched firms [28]. Finally, [48] updated and confirmed that restating firms exhibit significantly higher turnovers of CEOs, CFOs and external auditors post-restatement. Submit your manuscript electronically for review.

In terms of the economic consequences of FR, [11], [63] found negative market returns for accounting problem announcements, and that the negative reaction is most pronounced for firms with revenue recognition issues. Reference [35] reported that 689 of the restating companies lost an estimated $\$ 100$ billion in market capitalization, which is significant for the companies and shareholders involved. In addition, on average, accounting restatement leads to both decreases in expected future earnings and increases in the firm cost of equity capital [41]. Thus, this discussion leads to the development of the hypothesis below:

$\mathrm{H} 1$ : There is a negative relationship between FR and firm value.

\section{B. Moderating Effect of Corporate Governance Mechanisms}

This study employs several corporate governance variables to see whether good corporate governance can help in improving the value of a firm that is experiencing restatement.

1) Board Size

According to [32], the board of directors is an elected body with the function of minimising the agency costs arising from the separation of ownership and control in firms. An earlier study by [60] stated that the preferred board size must be between seven to fifteen directors.

Empirical studies show that large board size has a negative impact on firm performance [31], [20]. Similarly, according to [54], the board size of Malaysian companies is negatively correlated to firm performance.

Conversely, [39] found that boards consisting of many members are able to provide the resources needed by the company. Further, [21] confirmed that firms with a larger board size are related to less earnings management, while [47] argued that there is a positive relationship between board size and better updates of management earnings forecast (see, for example, [59], [68] and [52]. Thus, despite the conflicting views, it is expected that: restatements to examine the relationship between financial

$\mathrm{H} 2 \mathrm{a}$ : There is a significant positive relationship between FR and firm value when the firm has a larger board size.

2) Board Independence

Chapter 1 of the Bursa Malaysia Listing Requirements views an independent director as being independent of management and free from any business or other relationship which could interfere with the exercise of independent judgement or the ability to act in the best interest of an applicant or listed issuer [49] (Part A, Chapter 1). The revamped KLSE Listing Requirements 2001 state that at least one-third of the board should consist of independent, non-executive directors. Board structure or the proportion of independent directors sitting on the board is argued to affect firm performance either adversely or favourably. Thus, the definition provided indicates that independence of the board is crucial for internal governance and should be practiced by all firms.

The agency theory advocates believe that the existence of a majority of outside directors on the board is effective in reducing the agency conflict as they provide an avenue for an effective monitoring tool for the board [32]. The researchers suggest that outside directors are more efficient in monitoring the top management and in ensuring that there is no collusion with managers to expropriate the wealth of the stakeholders. Meanwhile, the proponents of managerial hegemony state that when the management is dominated by outside directors, the capability of the board of directors to fulfil their monitoring role is restricted and questionable [7]. Thus, the conflicting argument leads to the development of the hypothesis below:

$\mathrm{H} 2 \mathrm{~b}$ : There is a significant positive relationship between FR and the firm value of firms with a higher proportion of independent directors.

\section{3) CEO Duality}

There are two arguments regarding CEO duality, the agency theory view and the stewardship theory view. The stewardship theory views that a CEO who is at the same time acting as Chairman is able to enhance the decision making process [51]. As a steward to the firm, they are expected to serve and act in line with the principal's interest. Conversely, the CEO and Chairman roles need to be separated to maintain the effectiveness of monitoring [38].

A conceptually opposing view, the agency theory, suggests that CEO duality is negatively related to firm value. Consistent with the agency theory, [29] documented that firms that split the CEO and chairman positions due to investor pressure have significantly lower announcement returns and subsequent performance, and lower contributions of investment to shareholder wealth. The Istanbul Stock Exchange also reported that CEO duality has a negative impact on firm performance [30]. Similarly, [44] documented evidence that role duality/CEO duality restricts boards from monitoring and controlling the management. Despite the mixed argument, it is hypothesized that:

$\mathrm{H} 2 \mathrm{c}$ : There is a significant negative relationship between FR and firm value when a firm has CEO duality.

\section{4) Family Ownership}

Family ownership could affect the demand and supply of quality financial reporting in one of two competing ways: the entrenchment effect and the alignment effect [40]. This is based on the argument that family ownership can reduce agency costs through better alignment of the shareholder and managerial interest. Several

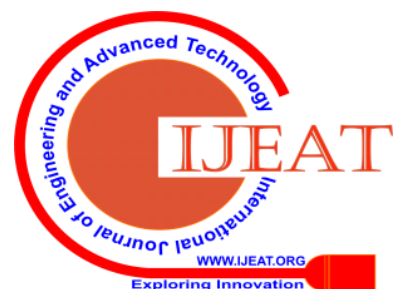


empirical studies on the effect of family ownership and performance in the US and UK found a non-linear relationship and argued that this is the result of a combination of the "convergence of interest" and "entrenchment" effect. According to [55], active family control is associated with higher profitability compared to non-family firms. Their findings could be because family control lowers the agency problem between owners and managers, but gives rise to conflicts between the family and minority shareholders when shareholder protection is low and control is high.

The Malaysian business environment is characterized by family-owned and government-owned companies [37]. Of the 238 Malaysian companies surveyed in [23], 67.2 per cent were in family hands and 13.4 per cent were owned by the government. Reference [42] reported that, on average, family ownership experiences a higher value than non-family ownership based on ROE, while, based on Tobin's $Q$ and ROA, the study found that firm value is lower in family than non-family ownership. Meanwhile, family ownership creates an incentive for controlling shareholders to expropriate other shareholders' wealth [32], [62]. Hence, the contradictory results above give rise to the development of the hypothesis below:

H3a:There is a significant positive relationship between FR and firm value when a firm has a high percentage of family ownership.

\section{5) Institutional Ownership}

In terms of external governance, institutional ownership is included in this study. According to [5], the total institutional shareholdings in Malaysia are about 13 per cent of the total market capitalisation of Bursa Malaysia. Reference [46] provided evidence that earnings are more informative as the holdings of the owner increase, thereby supporting the convergence of interest explanation for the owner-manager structure. They have an incentive to actively monitor management.

Thus, this study supports the theory that institutional owners help in enhancing better governance of financial reporting. Additionally, [22] examined the role of institutional investors in improving firm performance through the channel of corporate investment decisions. The findings show that the interaction between institutional investors and firm performance is significantly related to each other. In addition, they found that the monitoring role of institutional investors becomes more important when internal governance is weak, thus again, further supporting the theory that institutional investors contribute to good governance. Based on the positive impact of institutional ownership with firm value, it is hypothesized that:

$\mathrm{H} 3 \mathrm{~b}$ :There is a significant positive relationship between FR and the value of a firm with a higher percentage of institutional ownership.

\section{6) Political Connection}

Malaysian companies are unique in terms of their political connections. Political connection is argued to have an impact on firm value. Reference [33] studied political connections across many countries and documented that most politically connected companies are listed in countries with high levels of corruption and a weak legal system. The findings further revealed that the value of these companies increased when their executives enter politics. Reference [66] found that private firms with politically connected managers outperform those without such managers. It is argued that politically connected firms enjoy benefits from the government and political individuals. Reference [40] suggested that one direct channel through which political connections may benefit firms is by allowing them to borrow from state-owned banks on preferential terms. Reference [17] showed that in Thailand, firms with connections to banks and politicians obtained more long-term loans and needed less collateral during the period preceding the Asian financial crisis in 1997 compared to firms without such connections.

Conversely, [6] and [40] stressed that political relationships do not enhance shareholder value but rather fulfil the political goals of politicians. Reference [14] stated that politically connected firms are highly leveraged and exhibit poor accounting performance compared to their non-connected counterparts. However, a study conducted in Malaysia found that there is no evidence between political connection and firm performance [4]. Despite the no-linkage findings in Malaysia, it is hypothesized below that:

H4: There is a significant positive relationship between FR and the value of firms with a political connection.

\section{7) Audit Committee Expertise}

The issue of the background and experience of an audit committee that can affect the effectiveness of its auditing role has been raised by the Blue Ribbon Panel. The Panel suggests that the members of the audit committee should be financially literate (Blue Ribbon Panel). In Malaysia, the Malaysian Code on Corporate Governance (MCCG) also states that members of the audit committee should have a sufficient understanding of the financial reporting issues. Recently, the Listing Requirements of Bursa Malaysia also suggest that the audit committee should have at least one member registered under the local accounting professional body, the Malaysian Institute of Accountants, or at least have three years' experience after passing a professional examination and be a member of one of the specified accounting associations [61].

According to [56], firms with financial problems are unlikely to have audit committee members with financial expertise. Thus, the market reacts positively to the appointment of an audit committee with financial expertise [25]. Consistently, [67] argued that an audit committee equipped with financial experience and training will better understand the issue of earnings management. This is because the likelihood of a restatement is less for companies whose audit committee is entirely comprised of independent directors of which at least one member is a financial expert [1].

References [16], [13] found that both accounting and certain types of non-accounting financial expertise reduce earnings management for firms with weak alternate corporate governance mechanisms, but that independent audit committee members with financial expertise are more effective in mitigating earnings management. Using a sample size of 41 firms that issued fraudulent reports and 88 firms that restated annual results (without allegations of fraud) during the period 1991-1999, together with a matched pair control group of similar size, exchange listing, industry and auditor type, [2] documented a significant positive association between an audit committee that lacks a member with financial expertise and the occurrence of financial reporting restatement. In addition, [27] found a positive market reaction to the appointment of accounting

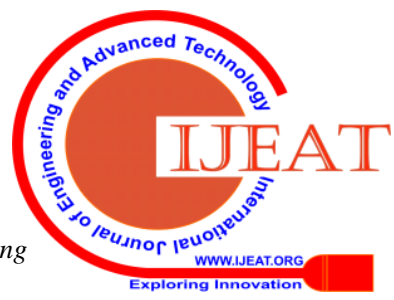


financial experts assigned to audit committees but no reaction to the non-accounting financial experts assigned to audit committees. This is consistent with accounting-based financial skills, but not broader financial skills, improving the audit committee's ability to ensure high-quality financial reporting.

Given the significant impact of audit committee expertise on financial restatement and fraudulent reporting, it is posited that:

H5: There is a significant positive relationship between financial restatement and firm value when firms have at least one member of the audit committee with financial expertise.

\section{RESEARCH DESIGN}

\section{A. Sample Selection}

The sample of this study covers all companies listed on the main board and second board of Bursa Malaysia from 2009 until 2015, which numbered 753 firms. Firms listed under the ACE Market, finance companies, trusts, closed and real investment trusts, as well as exchange-traded fund companies were excluded from this study due to the different nature of accounting treatment, governance and regulation. However, for the purpose of this study, firms that restated their previous financial statements were selected while other firms were excluded. This study follows the steps taken by [9] in which the keywords of "restate", "restated", or "prior year adjustment" were searched in all annual reports for evidence of restatement. The final sample before the selection of the financial restated annual reports was 4,816. After the selection of firms that restated their financial statements in accordance with the restatement categories defined by $\mathrm{GAO}^{1}$ for FR, the final sample of this study was 71. This study adopted a matched-pairs research design. For each of the 71 firms that restated their financial statements, the researcher identified a control firm. Consistent with prior research [26], [12] a control sample was identified with companies similar in respect of industry and size (total assets) but in which financial restatement was not detected. Table I presents a summary of the 71 restatement firms by industry.

Table I: Sample Distribution by Industry

\begin{tabular}{lcc}
\hline \multicolumn{1}{c}{ Industry } & \multicolumn{2}{c}{ Number of Firms } \\
& Total & \% of total \\
\hline Industrial Product & 13 & $18 \%$ \\
Consumer Product & 10 & $14 \%$ \\
Plantation & 7 & $10 \%$ \\
Trading \& Services & 24 & $34 \%$ \\
Construction & 9 & $13 \%$ \\
Property & 6 & $8 \%$ \\
Technology & 2 & $3 \%$ \\
\hline Total & $\mathbf{7 1}$ & $\mathbf{1 0 0 \%}$ \\
\hline
\end{tabular}

\section{B. Models and Variables}

We use the following regression model to analyse the relationship between financial restatement and firm value. Model 1:

$\mathrm{Q}=\beta_{0}+\beta_{1} \mathrm{RES}+\beta_{9} \mathrm{LEV}+\beta_{10} \mathrm{LN} \_\mathrm{SIZE}+\varepsilon$

\footnotetext{
${ }^{1}$ Refer to Appendix 1 for GAO definition of restatement.
}

In addition, we also examine whether corporate governance variables moderate the relationship tested on the interactions of the governance mechanisms with financial restatement and firm value. Thus, Models 2 and 3 are used.

Model 2:

$\mathrm{Q}=\beta_{0}+\beta_{1} \mathrm{RES}+\beta_{2} \mathrm{BODSIZE}+\beta_{3} \mathrm{BODIND}+$ $\beta_{4}$ DUALITY $+\beta_{5}$ FAMILY $+\beta_{6}$ INSTOWN $+\beta_{7}$ POLITICS $+\beta_{8}$ EXPERTS $+\beta_{9}$ LEV $+\beta_{10}$ LN_SIZE $+\varepsilon$

Model 3:

$\mathrm{Q}=\beta_{0}+\beta_{1}$ RES $+\beta_{2}$ BODSIZE $+\beta_{3}$ BODIND + $\beta_{4}$ DUALITY $+\beta_{5}$ FAMILY $+\beta_{6}$ INSTOWN $+\beta_{7}$ POLITICS $+\beta_{8}$ EXPERTS $+\beta_{9}$ LEV $+\beta_{10}$ LN_SIZE + $\beta_{11}$ RES*BODSIZE $+\beta_{12}$ RES*BODIND + $\beta_{13}$ RES*DUALITY $+\beta_{14}$ RES*FAMILY + $\beta_{15}$ RES*INSTOWN $+\beta_{16}$ RES*POLITICS + $\beta_{17}$ RES*EXPERTS $+\varepsilon$

Tobin's Q is used to measure the dependent variable, firm value $(Q)$. Reference [53] argued that Tobin's $Q$ is a suitable proxy for firm value. Similarly, in a study of the Singaporean capital market, Tobin's $Q$ was used as a measurement for firm value [19] also used Tobin's $Q$ as a proxy for firm value.

Tobin's Q, as used by [53], is computed as the sum of market value of equity and book value of debt, all divided by the book value of assets.

$$
Q=\frac{M V_{\text {equity }}+B V_{\text {debt }}}{B V_{\text {assets }}}
$$

Where:

MV equity : Market value of equity

BV debt : Book value of debt

BV asset : Book value of assets

Data for the independent variable, financial restatement, were extracted from the annual reports available on the website of Bursa Malaysia. Consistent with [9] and [53], financial restatement is measured using dichotomous variables. Firms that restate their financial statements in the year examined were coded as 1 , and the matched firms are coded as 0 .

The moderating variable used in this study is corporate governance mechanism. The governance variables involved are board size (BODSIZE), board independence (BODIND), CEO duality (DUALITY), family ownership (FAMILY), institutional ownership (INSTOWN), political connection (POLITICS), and audit committee having financial expertise (EXPERTS). Similar to the measurement used by [3], board size in this study is measured based on the total number of directors on the board of the restated firms. Board independence (BODIND) is measured by the number of independent directors who serve on the board, which is similar to the measure used by [18]. It is suggested that a large number of independent directors on the board can mitigate the agency problem because independent directors are better in controlling and monitoring the opportunistic activities of the management [43]. CEO duality 
(DUALITY) is used to test the effects of duality on financial restatement firm value. Consistent with [30], DUALITY is a dummy variable that carries a value of one if the CEO also serves as chairman, and zero otherwise. In essence, empirical evidence suggests that a firm has better performance when it is family-managed and institutional-managed [64], [34], [6]. In this study, family ownership (FAMOWN) is measured based on the percentage of family ownership in the top ten largest shareholders, with a larger value indicating greater family interests in the firm. Similarly, the measure of the level of institutional ownership (INSTOWN) is the percentage of shares held by institutional shareholders [top five institutional investors, namely, Employees Provident Fund (EPF), Lembaga Tabung Angkatan Tentera (LTAT), Permodalan Nasional Berhad (PNB), Lembaga Urusan Tabung Haji (LUTH), and Social Security Organisation (SOCSO)] in top ten largest shareholders [6]. Specifically, the political connections variable is a dummy variable that indicates whether political connections were present in an organization. In this study, the POLITICS variable is coded " 1 " if the firms are owned and controlled by individuals, next of kin, relatives, or associates linked to the top government officials of the political parties and leadership in Malaysia; and " 0 " otherwise; this is similar to the measure used by [45].

Audit committee financial expertise (EXPERTS) is a dummy variable in which if one of the audit committee members has financial expertise, it is coded as one, and zero otherwise. This measurement is consistent with the measurement used by [13].

\section{EMPIRICAL RESULTS}

\section{A. Descriptive Statistics}

\section{1) Univariate Analysis}

The descriptive statistics for all the variables used are shown in Table II-IV. The statistics show the total number of observations in this study, minimum and maximum amount of each variable, and mean and standard deviation. The minimum and maximum values present the lowest and highest values for the variables used. As for the mean, it portrays the average value and the standard deviation indicates how far away the average data values typically are. Table II shows the descriptive statistics for firm value, that is, the value of Tobin's Q. As reported in this table, the maximum value of Tobin's Q calculated in this study is 9.702 as compared to the minimum value of 0.002 .

Table II: Descriptive Statistics for Dependent Variable for Sample Firms (2009-2015, n: 142)

\begin{tabular}{lllll}
\hline & Mean & Minimum & Maximum & Std. Dev \\
\hline $\mathrm{Q}$ & 1.051 & 0.002 & 9.702 & 1.214 \\
\hline
\end{tabular}

Q: Firm value measured by Tobin's Q

Table III shows the descriptive statistics for the independent variable: financial restatement. Since a dummy variable is used for financial restatement firms, the value only involved " 1 " and " 0 ". Thus, the results indicate that the average value for this type of variable is 0.50 with a standard deviation of 0.502 . Meanwhile, Table IV shows restatements based on the sectorial classification of Bursa Malaysia.

Table III: Descriptive Statistics for Independent Variable for Sample Firms (2009-2015, n: 142)

\begin{tabular}{lllll}
\hline & Mean & Minimum & Maximum & Std. Dev \\
\hline RES & 0.5 & 0 & 1 & 0.502 \\
\hline
\end{tabular}

RES= Dummy variable of " 1 " if firm restates its previous financial statement, and " 0 " otherwise.

Table IV: Financial Restatements based on Bursa Malaysia Sectorial Classification (2009-2015, n: 142)

\begin{tabular}{|c|c|c|c|c|c|c|c|c|}
\hline Industrial classification & 2009 & 2010 & 2011 & 2012 & 2013 & 2014 & 2015 & Total \\
\hline Trading and services & 6 & 4 & 3 & 2 & 5 & 6 & & 26 \\
\hline Consumer products & 2 & 1 & 2 & 1 & 2 & 1 & 2 & 11 \\
\hline Properties & & 3 & 1 & 1 & & & & 5 \\
\hline Industrial products & 1 & 4 & 2 & 3 & & & 4 & 14 \\
\hline Constructions & 1 & 2 & 3 & & 1 & 1 & 2 & 10 \\
\hline Plantation & & & 2 & & & 1 & 2 & 5 \\
\hline Total & 10 & 14 & 13 & 7 & 8 & 9 & 10 & 71 \\
\hline
\end{tabular}

Table V: Pearson Correlation Matrix of Tested Variables (2009-2015, n: 142)

\begin{tabular}{|c|c|c|c|c|c|c|c|c|c|c|c|}
\hline & Q & RES & BODSIZE & BODIND & DUALITY & FAMILY & INSTOWN & POLITICS & EXPERTS & LEV & LN_SIZE \\
\hline $\mathrm{Q}$ & 1 & & & & & & & & & & \\
\hline RES & $-.369 * *$ & 1 & & & & & & & & & \\
\hline BODSIZE & -0.017 & $-.221 * *$ & 1 & & & & & & & & \\
\hline BODIND & 0.06 & 0.091 & $-.226 * *$ & 1 & & & & & & & \\
\hline DUALITY & 0.07 & 0.15 & -0.065 & 0.006 & 1 & & & & & & \\
\hline FAMILY & 0.094 & $.176^{*}$ & -0.042 & -0.051 & 0.137 & 1 & & & & & \\
\hline INSTOWN & -0.064 & 0.047 & 0.132 & -0.019 & -0.056 & -0.097 & 1 & & & & \\
\hline POLITICS & 0.071 & 0.141 & 0.009 & 0.006 & $-.182 *$ & -0.09 & 0.082 & 1 & & & \\
\hline EXPERTS & $.248 * *$ & $-.518^{* *}$ & 0.15 & 0.057 & -0.154 & 0.009 & -0.061 & -0.12 & 1 & & \\
\hline LEV & -0.134 & 0.073 & 0.111 & -0.053 & 0.043 & -0.123 & 0.006 & 0.097 & $-.183^{*}$ & 1 & \\
\hline LN_SIZE & -0.011 & -0.002 & $.168 *$ & -0.124 & 0 & $-.186^{*}$ & $.219 * *$ & $.197 *$ & 0.081 & $.261 * *$ & 1 \\
\hline
\end{tabular}

Notes: *** Significant at 0.01 level; **Significant at 0.05 level; *Significant at 0.10 level.

$\mathrm{Q}=$ measured by Tobin's $\mathrm{Q}, \mathrm{RES}=$ takes value " 1 " if firms restates previous financial statements, " 0 " otherwise, BODSIZE $=$ Total number of directors on board, BODIND $=$ Proportion number of independent directors on board, DUALTIY = takes value of " 1 " if the firm do not separates the CEO and Chairman, and " 0 " if otherwise, FAMILY= Total percentage of family ownership for top ten largest shareholding, INSTOWN= Proportion of institutional 
ownership for top five institutional investors, POLITICS= Dummy variables states " 1 " if firm's is politically connected, and "0" otherwise, EXPERTS= Takes value as "1" if at least one member of audit committee has financial expertise, LEV= Ratio of total debt to total assets, and LN_SIZE= Log of total assets

Table IV reports the Pearson's correlations between financial restatement and firm value. From Table V, it can be seen that financial restatement (RES) is significantly and negatively correlated with firm value (Q) (-0.369). It is expected that financial restatement would adversely affect firm value. The possible reason is that financial restatement can signal that the previous financial statement issued is not reliable or dependable for investors. In addition, other variables are significantly correlated - positively or negatively - to each other. As shown in Table V, the Tobin's $\mathrm{Q}$ and corporate governance variable, namely, EXPERTS is positively and significantly correlated with each other (0.248). However, the other variables - board size (BODSIZE), board independence (BODIND), CEO duality (DUALITY), family ownership (FAMILY) and institutional (INSTOWN) ownership as well as political connection (POLITICS) factors - are not significantly correlated with Tobin's Q. Board independence (0.06), CEO duality (0.07), family ownership (0.94) and political connections are positively related with Tobin's Q.

Furthermore, by referring to the table presented, the correlation between board size and financial restatement shows a negative direction (-0.221) and is significant. Thus, small board size can initiate or promote financial restatement. One possible reason could be that when the number of directors who sit on the board is small, the monitoring power is less effective. This confirms the finding of [21] that firms with larger board size are related to less earnings management. Surprisingly, at the 0.1 level of significance, a higher ownership of family results in a higher case of financial restatement. However, this finding is supported by [32], [62] who argued that family ownership creates an incentive for controlling shareholders to expropriate the wealth of other shareholders. A possible reason for this result is that when the family ownership is high, the family members try to hide any problems faced by the firm to ensure its going concern and good image. Therefore, they will try as best as possible to make the financial statements look 'good'. It is also worth noting that the correlation between audit committee, financial expertise and FR is significantly correlated in a negative direction. This suggests that when a member of the audit committee has financial expertise, they can reduce the likelihood of financial restatement. This is because by using their vast knowledge of financial matters, they are able to provide firms with a good foundation of financial management and provide more useful audit advice and service.

In addition, this study found an insignificant correlation between financial restatement and BODIND, DUALITY, INSTOWN and POLITICS. In addition, LEV is positively related with the main independent variable but insignificant. Financial restatement is negatively correlated with size $(-0.11)$, which shows that the smaller the size of the firms, the higher the probability of firms to restate their financial statements. Concerning the corporate governance variables, in Table $\mathrm{V}$, BODSIZE was found to be negatively, significantly correlated with BODIND at the 5 per cent level of significance $(-0.226)$, suggesting that a proportion of board independence is related to the board structure of the firm. Additionally, BODSIZE is positive and significantly correlated to LN_SIZE, which indicates that large firms in Malaysia have a larger board size compared to smaller firms. Interestingly, BODIND is not significantly correlated to the other variables tested. The possible explanation could be that the existence of independent directors on the board in the Malaysian scenario could be merely just to fulfil the requirement of MCCG rather than totally exercising the role of independent directors. DUALITY is found to be negatively correlated with POLITICS at the 10 per cent level. This shows that the position of CEO and chairman is separated in politically connected firms.

Overall, the Pearson's correlations between the variables are low indicating that multicollinearity is not likely to pose a problem in our regression analyses.

\section{A. Logistic Regression Results \\ 1) Results of Financial Restatements (RES) and Firm Value (Q)}

Table VI exhibits the regression results for testing the H1 hypothesis for which this study employed RES as the main independent variable. The results in Model 1 indicate that R2 and the adjusted $\mathrm{R} 2$ are 0.148 and 0.130 , respectively. The adjusted R2 demonstrated in this model is considered quite high compared to a study in the Chinese market in which the reported adjusted $\mathrm{R} 2$ is 0.03 . The regression was statistically significant at the 1 per cent level with an F-value of 8.001. This table analyses how financial restatement affects firm value. As expected, this study found a significant negative relationship between financial restatement and firms. This indicates that a firm that restates its previous financial statement will face a decrease in its firm value. Investors gradually lose confidence and belief in the management of the firms. They find that their previous investment decision is mistaken because they made the decision using the uncorrected financial statement. This can be to the extent whereby they feel deceived by the management in a more severe restatement issue. Thus, this suggests that financial restatement impairs investor confidence in the firms, and, eventually, will reduce the value of Tobin's $Q$ in the long run. The results of this study confirm and support the literature from past studies [11], [53], and [58].

Table VI: Regression Results for Model 1

\begin{tabular}{llll}
\hline Variables & Coefficient & t-statistic & p- value \\
\hline (Constant) & 95.563 & 1.571 & 0.000 \\
RES & -29.589 & $\mathbf{- 4 . 5 8 * * *}$ & $\mathbf{0 . 0 0 0 * * *}$ \\
LEV & -20.824 & -1.377 & 0.171 \\
LN_SIZE & 1.320 & 0.212 & 0.833 \\
Industry fixed & Yes & & \\
R2 & 0.148 & & \\
Adjusted R2 & 0.130 & & \\
F-Statistic & $\mathbf{8 . 0 0 1 * * *}$ & & \\
\hline
\end{tabular}


Notes: *** Significant at 0.01 level; ** Significant at 0.05

level; * Significant at 0.10 level. $\mathrm{Q}=$ measured by Tobin's $\mathrm{Q}$, $\mathrm{RES}=$ takes value " 1 " if firm restates previous financial statement, " 0 " otherwise, LEV= Ratio of total debt to total assets, and LN_SIZE= Log of total assets

\section{2) Results of Moderating Variable}

A different set of regression analyses was undertaken to test the moderating variables. Regression Model 1 is directly related to the direct effect between the independent and dependent variables. Various corporate governance variables were tested in this study too see whether there is a moderating effect on the relationship of financial restatement and firm value.

Thus, Table VII summarises the regression of Model 2 with the inclusion of a corporate governance mechanism. In relation to Model 2, R2 is 48 per cent and the adjusted R2 is 17.4 per cent. The full model can be considered as highly significant. This indicates that a 17.4 per cent variation in firm value is influenced by the independent, moderating and control variables. Next, Model 2 shows that the coefficient financial restatement (RES) is negatively and significantly (0.000) related to firm value. The findings also show a significantly positive association between firm value and DUALITY (0.060), FAMILY (0.055) and POLITICS (0.024). Whereas, the results is insignificant between firm value and other variables namely; BODSIZE (0.337), BODIND (0.306) and INSTOWN (0.745).

Table VII: Regression Results for Model 2

\begin{tabular}{llll}
\hline Variables & Coefficient & t-statistic & p-value \\
\hline (Constant) & 79.776 & 2.931 & 0.004 \\
RES & -35.744 & $\mathbf{- 4 . 5 8 8 * * *}$ & $\mathbf{0 . 0 0 0 * * *}$ \\
BODSIZE & -2.225 & -0.963 & 0.337 \\
BODIND & 0.294 & 1.027 & 0.306 \\
DUALITY & 13.362 & $\mathbf{1 . 8 9 6}^{*}$ & $\mathbf{0 . 0 6 0 *}$ \\
FAMILY & 0.361 & $\mathbf{1 . 9 3 6}^{*}$ & $\mathbf{0 . 0 5 5 *}$ \\
INSTOWN & -0.029 & -0.326 & 0.745 \\
POLITICS & 15.259 & $\mathbf{2 . 2 8 9} * *$ & $\mathbf{0 . 0 2 4} * *$ \\
EXPERTS & 4.663 & 0.555 & 0.580 \\
LEV & -17.103 & -1.124 & 0.263 \\
LV_SIZE & 2.272 & 0.344 & 0.731 \\
Industry fixed & Yes & & \\
R2 & 0.482 & & \\
Adjusted R2 & 0.174 & & \\
F- statistic & $\mathbf{3 . 9 7 2 * * *}$ & &
\end{tabular}

Notes: *** Significant at 0.01 level; **Significant at 0.05 level; *Significant at 0.10 level. $\mathrm{Q}=$ measured by Tobin's $\mathrm{Q}, \mathrm{RES}=$ takes value " 1 " if firm restates previous financial statement, " 0 " otherwise, BODSIZE= Total number of directors on board, BODIND $=$ Proportion of number of independent directors on board, DUALTIY= takes value of " 1 " if the firm does not separate the CEO and Chairman, and " 0 " if otherwise, FAMILY= Total percentage of family ownership for top ten largest shareholdings, INSTOWN= Proportion of institutional ownership for top five institutional investors, POLITICS= Dummy variables stated as" 1 " if firm is politically connected, and "0" otherwise, EXPERTS= Takes value of" 1 " if at least one member of the audit committee has financial expertise, LEV= Ratio of total debt to total assets, and LN_SIZE= Log of total assets

In relation to Model 3, the Model 2 is again regressed together with the inclusion of the interaction of financial restatement and the corporate governance variables. Model 3 shows a slightly higher adjusted R2 with a value of 0.214 . This shows that a 21.4 per cent change in firm value is contributed by the independent, moderating and control variables. Contrary to Model 2, Model 3 exhibits that financial restatement is insignificantly related to firm value. However, the direction of the association is consistently negative.

This study finds that the moderating variables - DUALITY (0.040) and FAMILY (0.005) - remain significantly related to firm value, thus demonstrating the robustness of the model used. However, it is worth noting that CEO duality is positively associated with firm value. One possible reason could be that when the same CEO sits as chairman of the board, he can reduce the time taken in decision-making. Thus, the time saved can be used to focus on the goal of the firms in increasing shareholder wealth. Given that the Malaysian capital market is mostly owned by family members, another reason could be that CEO duality is probably exercised by family firms in which they will try their very best to achieve good performance and increase the value of the firm. The FAMILY variable stood at a very significant level with firm value. This indicates that family ownership can reduce the agency problem and that their actions are aligned with the interests of the shareholders (principal). Eventually, firm value will increase due to the reduction in agency costs. This result is consistent with [55], who found that active family control is associated with higher profitability compared to non-family firms but is inconsistent with a previous Malaysian study in which the author argued that based on Tobin's Q and ROA, firm value is lower in family than non-family ownership. This is based on the notion that family firms invest a high share of their assets in a certain firm, which, subsequently, might invest in a lower-risk-lower-return business in which the return is less profitable. POLITICS $(0.042)$ is positively related to firm value and significant at the 5 per cent level.

Concerning the moderating role of board size as one of the governance mechanism, hypotheses $\mathrm{H} 2 \mathrm{a}$, which predicts that larger board size in financial restatement firms will positively influence firm value, is rejected. The result of the regression shows that the interaction of RES $x$ BODSIZE is negative but insignificant. Therefore, from the results, it can be said that, probably, regardless of the board size in restating firms, the value of the restating firm will continually reduce as a penalty from outside market players. $\mathrm{H} 2 \mathrm{~b}$ posits that there is a significant positive relationship between financial restatement and firm value for firms with a higher proportion of independent directors. The table shows that there is a positive but insignificant relationship. Thus, again, the hypothesis developed earlier is rejected. In terms of the interaction of RES x DUALITY, the result is negative but significant; hence, hypothesis $\mathrm{H} 2 \mathrm{c}$ is rejected.

With regard to the interaction variables for financial restatement and corporate governance, this study finds that the interaction of RES $\mathrm{x}$ FAMILY is negatively and significantly (0.043) associated with firm value. Thus, the result rejects $\mathrm{H} 3 \mathrm{a}$, which posits that there is a positive relationship between financial restatement and firm value when family ownership is high. The reason could be because family ownership in restating companies does not mitigate

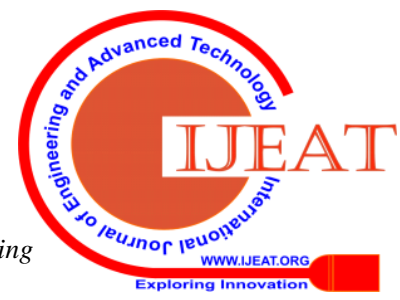


the agency problem, but rather initiates an increase in agency problems. This might be because, when a company faces financial restatement, family members who hold shares in that firm will pressure the management to further 'make up' their financial statement to 'restore' investors' confidence.

As expected in $\mathrm{H} 3 \mathrm{~b}$, this study reveals that the interaction of RES x INSTOWN is positively and significantly associated with firm value $(0.005)$. The result explains that a higher percentage of institutional ownership will promote an increase in the value of financial restatement firms. Perhaps this is because the effect of the monitoring duty exercised by institutional investors is becoming more effective in the case of financial restatement firms. The institutional investors are perceived as being the watchdog for any irregularities initiated or undertaken by the management. It is argued that institutional ownership mitigates and mediates the self-serving behaviour of corporate managers in financial reporting [57]. Hence, one could agree that the existence of block holders, particularly, can mitigate or moderate the severity brought by financial restatement on firm value in the long term. The result of this study is consistent with [65] in which he documented a positive relationship between the Taiwanese institutional ownership and firm performance. $\mathrm{He}$ argued that institutional owners have better expertise for monitoring. In addition, [22] examined the role of institutional investors in improving firm performance through the channel of corporate investment decisions. The findings show that the interaction between institutional investors and firm performance is significantly related to each other. In addition, they found that the monitoring role of institutional investors becomes more important when internal governance is weak. This further emphasizes that the existence of institutional ownership in restating firms will enhance the governance of the firms. Thus, the study accepts hypothesis $\mathrm{H} 3 \mathrm{~b}$ since the interaction of financial restatement and institutional ownership shows a significant positive effect on firm value.

In $\mathrm{H} 4$, it is expected that there is a significant positive relationship between financial restatement and the value of firms with a political connection. Surprisingly, the hypothesis is rejected when the interaction of RES and POLITICS is negatively but insignificantly associated with firm value. Thus, this result confirms that political connection at some point can be a grabbing hand, rather than a helping hand. This finding is consistent with [14] who stated that politically connected firms are highly leveraged and exhibit poor accounting performance compared to their non-connected counterparts. Furthermore, this study fills the gap left by [4] who found no evidence between political connection and firm performance.

With respect to the interaction between RES and the audit committee financial expertise, as depicted in Table VIII, the result shows a negative but not significant relationship with firm value. This study fails to support $\mathrm{H} 5$, which predicted a positive relationship between financial restatement and firm value when the firm has at least one member of the audit committee with financial expertise. Most probably, audit committee expertise can only enhance the auditing procedure in the restating firm rather than increase the investor's investment, which, in turn, will lead to better firm value.
Table VIII: Regression Results for Model 3

\begin{tabular}{lrrr}
\hline Variables & Coefficient & t- statistic & p-value \\
\hline (Constant) & 50.411 & 1.571 & 0.119 \\
RES & -7.977 & -0.229 & 0.819 \\
BODSIZE & -2.103 & -0.809 & 0.42 \\
BODIND & 0.198 & 0.572 & 0.568 \\
DUALITY & 20.448 & $\mathbf{2 . 0 7 7} * *$ & $\mathbf{0 . 0 4 0} * *$ \\
FAMILY & 0.805 & $\mathbf{2 . 8 3} * *$ & $\mathbf{0 . 0 0 5} * * *$ \\
INSTOWN & 0.015 & 0.159 & 0.874 \\
POLITICS & 19.352 & $\mathbf{2 . 0 5 5} * *$ & $\mathbf{0 . 0 4 2} * *$ \\
EXPERTS & 10.558 & 0.708 & 0.48 \\
LEV & -14.684 & -0.935 & 0.352 \\
LN_SIZE & 5.044 & 0.753 & 0.453 \\
RESxBODSIZE & -2.269 & -0.495 & 0.622 \\
RESxBODIND & 0.061 & 0.136 & 0.892 \\
RESxDUALITY & -8.99 & -0.665 & 0.508 \\
RESxFAMILY & -0.747 & $\mathbf{- 2 . 0 4 1} * *$ & $\mathbf{0 . 0 4 3} * *$ \\
RESxINSTOWN & 0.228 & $\mathbf{2 . 8 8 8} * * *$ & $\mathbf{0 . 0 0 5 * * *}$ \\
RESxPOLITICS & -7.486 & -0.555 & 0.58 \\
RESxEXPERTS & -11.129 & -0.648 & 0.518 \\
Industry fixed & Yes & & \\
R2 & 0.309 & & \\
Adjusted R2 & 0.214 & & \\
F-Statistic & $\mathbf{3 . 2 5 7 * * *}$ & & \\
\hline Not & & & \\
\hline
\end{tabular}

Notes: *** Significant at 0.01 level; **Significant at 0.05 level; *Significan at 0.10 level. $\mathrm{Q}=$ measured by Tobin's $\mathrm{Q}, \mathrm{RES}=$ takes value " 1 " if firm restates previous financial statement, " 0 " otherwise, BODSIZE $=$ Total number of directors on board, BODIND $=$ Proportion of number of independent directors on board, DUALTIY= takes value of " 1 " if the firm does not separate the CEO and Chairman, and "0" if otherwise, FAMILY= Total percentage of family ownership for top ten largest shareholding, INSTOWN= Proportion of institutional ownership for top five institutional investors, POLITICS= Dummy variables states "1" if firm is politically connected, and "0" otherwise, EXPERTS= Takes value of" 1 " if at least one member of audit committee has financial expertise, $L E V=$ Ratio of total debt to total assets, and LN_SIZE= Log of total assets

\section{CONCLUSION}

The issue of corporate scandals, fraud, and fraudulent financial reporting and restatement is a global issue, which is also found in Malaysia. Recently, Malaysia witnessed a spate of corporate scandals involving listed companies, which, to a certain extent, have seriously undermined investors' confidence. While Malaysia boasts a world-class framework for corporate governance, previous years have uncovered some cases of phantom invoices, doubtful accounts, and mismanagement lurking in some of its listed companies. In particular, the recent increase in the number of financial restatement cases provides the main motivation for the study of the interrelationships between financial restatements and firm value in Malaysia. We find that financial restatements do adversely impact firm value. The results show that financial restatements negatively and significantly affect firm value, which indicates that financial restatements signal a red flag concerning the firm's credibility, and that management is doing something wrong with their investment, which leads them to issue a restatement of the financial statement.

The results of the interaction of RES and board independence, and the interaction between RES and CEO duality rejects the hypothesis developed 
earlier. Probably, the interaction of financial restatement with board independence is not significant to firm value because the existence of independent directors merely fulfils the requirement by MCCG rather than exercise the real meaning of 'independence'; hence, this study supports the findings of [9]. Additionally, [8] suggested that neither board independence nor CEO duality, nor the joint effects of these two provide any significant effect on firm performance.

On the one hand, it was found that the interaction of financial restatement and family ownership has a significant impact on firms. The hypothesis expected a significant positive relationship between financial restatement and firm value when the firm has a high percentage of family ownership. However, the result from the regression model identified that the interaction is negatively associated with firm value. This is contradictory to [55] who found that active family control is associated with higher profitability compared to non-family firms. Interestingly, this finding further supports the evidence provided by [42], as based on Tobin's Q and ROA, the study finds that firm value is lower in family than non-family ownership. This is probably because family-run firms are trying to safeguard their vast investment compared to other minority shareholders by merely altering or making up the financial statements to make it more 'beautiful' and 'mesmerizing'.

On the other hand, this study finds that the interaction between financial restatement and institutional ownership is positively and significantly associated with firm value. This indicates that the active or increased involvement of institutional ownership directly increases the value of the restating firm. This is because investors see institutional investors as their watchdog and a means for promoting the restoration of investors' confidence. Institutional investors bring expertise to monitoring [65]. For a firm experiencing financial restatement, the existence of institutional investors is said to better enhance its weak internal governance. As for the political connection factor and audit committee financial expertise, the results reject the hypothesis since the relationship is insignificant.

This study contributes to the literature in several areas. It provides a contribution to the understanding of the association between financial restatement and firm value, and, perhaps, assists the regulatory bodies to evaluate whether the existing requirements, rules and codes of conduct imposed are suitable or updated to address the current issues, and, thus, helps them to regulate and structure new rules that suit the Malaysian context and protect the interests of the market players, especially the shareholders. Additionally, this study finds that corporate governance mechanisms play an important role in enhancing monitoring roles and ensuring an increase in firm value. Thus, the results of this can also contribute to the governance structure of financial restatement firms or non-restated firms. Furthermore, the results show that governance does matter in moderating the adverse effect of financial restatement on firm value.

This study has several caveats that may influence the interpretation of the results. With regards to financial restatement, this study ignores whether the restatement involved income increasing or income decreasing. The categorisation or type of restatement is based on the categories provided by GAO with the exclusion of restatements due to announcements involving stock splits, changes in accounting principles, and other financial statement restatements that were not made to correct mistakes in the application of accounting standards. It would be interesting for future studies to be conducted on public listed firms concerning the effect of financial restatements on non-financial aspects, such as CEO turnover and management turnover. Finally, future research could also focus on the impact of income increasing and income decreasing of financial restatements on the market share prices in the Malaysian context.

\section{APPENDIX}

A. Appendix 1: Restatement category according to GAO definition

\begin{tabular}{|c|c|}
\hline Category & Description \\
\hline $\begin{array}{l}\text { Acquisitions } \\
\text { and mergers }\end{array}$ & $\begin{array}{l}\text { Restatements of acquisitions or mergers } \\
\text { that were improperly accounted for or } \\
\text { not accounted for at all. These include } \\
\text { instances in which the wrong accounting } \\
\text { method was used or losses or gains } \\
\text { related to the acquisition were } \\
\text { understated or overstated. This does not } \\
\text { include in-process research and } \\
\text { development or restatements for } \\
\text { mergers, acquisitions, and discontinued } \\
\text { operations when appropriate accounting } \\
\text { methods were employed }\end{array}$ \\
\hline Cost or expense & $\begin{array}{l}\text { Restatements due to improper cost } \\
\text { accounting. This category includes } \\
\text { instances of improperly recognizing } \\
\text { costs or expenses, improperly } \\
\text { capitalizing expenditures, or any other } \\
\text { number of mistakes or improprieties that } \\
\text { led to misreported costs. It also includes } \\
\text { restatements due to improper treatment } \\
\text { of tax liabilities, income tax reserves, } \\
\text { and other tax-related items }\end{array}$ \\
\hline $\begin{array}{l}\text { In-process } \\
\text { research and } \\
\text { development }\end{array}$ & $\begin{array}{l}\text { Restatements resulting from instances in } \\
\text { which improper accounting } \\
\text { methodologies were used to value } \\
\text { inprocess research and development at } \\
\text { the time of an acquisition }\end{array}$ \\
\hline Other & $\begin{array}{l}\text { Any restatement not covered by the } \\
\text { listed categories. Cases included in this } \\
\text { category include restatements due to } \\
\text { inadequate loan-loss reserves, } \\
\text { delinquent loans, loan write-offs, or } \\
\text { improper accounting for bad loans and } \\
\text { restatements due to fraud, or accounting } \\
\text { irregularities that were left unspecified }\end{array}$ \\
\hline Reclassification & $\begin{array}{l}\text { Restatements due to improperly } \\
\text { classified accounting items. These } \\
\text { include restatements due to } \\
\text { improprieties such as debt payments } \\
\text { being classified as investments }\end{array}$ \\
\hline
\end{tabular}




\begin{tabular}{|c|c|}
\hline $\begin{array}{l}\text { Related-party } \\
\text { transactions }\end{array}$ & $\begin{array}{l}\text { Restatements due to inadequate } \\
\text { disclosure or improper accounting of } \\
\text { revenues, expenses, debts, or assets } \\
\text { involving transactions or relationships } \\
\text { with related parties. This category } \\
\text { includes those involving special purpose } \\
\text { entities }\end{array}$ \\
\hline $\begin{array}{l}\text { Restructuring, } \\
\text { assets, or } \\
\text { inventory }\end{array}$ & $\begin{array}{l}\text { Restatements due to asset impairment, } \\
\text { errors relating to accounting treatment of } \\
\text { investments, timing of asset } \\
\text { write-downs, goodwill, restructuring } \\
\text { activity, and inventory valuation, and } \\
\text { inventory quantity issues }\end{array}$ \\
\hline $\begin{array}{l}\text { Revenue } \\
\text { recognition }\end{array}$ & $\begin{array}{l}\text { Restatements due to improper revenue } \\
\text { accounting. This category includes } \\
\text { instances in which revenue was } \\
\text { improperly recognized, questionable } \\
\text { revenues were recognized, or any other } \\
\text { number of mistakes or improprieties that } \\
\text { led to misreported revenue }\end{array}$ \\
\hline $\begin{array}{l}\text { Securities } \\
\text { related }\end{array}$ & $\begin{array}{l}\text { Restatements due to improper } \\
\text { accounting for derivatives, warrants, } \\
\text { stock options and other convertible } \\
\text { securities }\end{array}$ \\
\hline
\end{tabular}

Note: The study excluded announcements involving stock splits, changes in accounting principles, and other financial restatements that were not made to correct mistakes in the application of accounting standards.

Source: [36]

\section{ACKNOWLEDGMENT}

The authors would like to express their gratitude to the Ministry of Education of Malaysia for funding the research project through the FRGS grant. Our appreciation also goes to the Faculty of Accountancy, Universiti Teknologi MARA and Accounting Research Institute, Universiti Teknologi MARA for facilitating this research project.

\section{REFERENCES}

1. Abbott, L. J., Parker, S. and Peters, G. F. (2004). Audit Committee Characteristics and Restatements. Auditing: A Journal of Practice \& Theory, vol. 23(1), 69-87.

2. Abbott, L. J., Parker, S. and Peters, G. F. (2002), Audit Committee Characteristics and Financial Misstatement: A Study of the Efficacy of Certain Blue Ribbon Committee Recommendations. Available: http://papers.ssrn.com/sol3/papers.cfm?abstract_id=319125.

3. Abdul Rahman, R. and Mohamed Ali, F. H. (2006). Board, Audit Committee, Culture, and Earnings Management: Malaysian Evidence. Managerial Auditing Journal, vol. 21(7), 783-803.

4. Abdul Wahab, E. A., How, J. and Verhoeven, P. (2007). The Impact of the Malaysian Code on Corporate Governance: Compliance, Institutional Investors and Stock Performance. Journal of Contemporary Accounting \& Economics, vol. 3(2), 106-129.

5. Abdul Wahab, E. A, How J. and Verhoeven, P. (2008). Corporate governance and institutional investors: evidence from Malaysia. Asian Academy of Management Journal of Accounting and Finance, vol. 4(2), 67-90.

6. Abdul Wahab, E. A., Mat Zain, M., James, K. and Haron, H. (2009). Institutional Investors, Political Connection and Audit Quality in Malaysia," Accounting Research Journal, vol. 22(2), 167-195.

7. Abdullah, S. N. (2004). Board Composition, CEO Duality and Performance among Malaysian Listed Companies. Corporate Governance, vol. 4(4), 47-61.

8. Abdullah, S. N. and Mohd-Nasir, N. (2004). Accrual Management and the Roles of Boards of Directors and Audit Committees among

Malaysian Listed Companies: Evidence during the Asian Financial Crisis," IIUM Journal of Management and Economics, vol. 12, 49-80.

9. Abdullah, S. N., Mohamad Yusof, N. Z. and Mohamad Noor, N. N. (2010). Financial Restatements and Corporate Governance among Malaysian Listed Companies. Managerial Auditing Journal, vol. 25(6), 526-552.

10. Ahmed, K. and Goodwin, J. (2007). An Empirical Investigation of Earnings Restatements by Australian Firms. Accounting \& Finance, vol. 47(1), 1-22.

11. Anderson, K. L. and Yohn, T. L. The Effect of 10-K Restatements on Firm Value, Information Asymmetries, and Investors' Reliance on Earnings. Working Paper: Georgetown University.

12. Beasley, M. S. (1996). An Empirical Analysis of the Relation between the Board of Director Composition and Financial Statement Fraud. Accounting Review, 443-465.

13. Bedard, J., Chtourou, S. M. and Courteau, L. (2004). The Effect of Audit Committee Expertise, Independence, and Activity on Aggressive Earnings Management. Auditing: A Journal of Practice \& Theory, vol. 23(2), 13-35.

14. Boubakri, N., Cosset, J. C. and Saffar, W. (2008). Political Connections of Newly Privatized Firms. Journal of Corporate Finance, vol. 14(5), 654-673.

15. Brown, D. L. and Marcus, L. C. (2004). Corporate Governance and Firm Performance. Working Paper: Georgia State University.

16. Carcello, J., Hollingsworth, C., Klein, A. and Neal, T. (2006), Audit Committee Financial Expertise, Competing Corporate Governance Mechanisms, and Earnings Management. (february 2006). Available: http://papers.ssrn.com/sol3/papers.cfm?abstract_id=887512.

17. Charumilind, C., Kali, R. and Wiwattanakantang, Y. (2006). Connected Lending: Thailand before the Financial Crisis. The Journal of Business, vol. 79(1), 181-218.

18. Che Haat, H. H., Abdul Rahman, R. and Mahenthiran, S. (2008). Corporate Governance, Transparency, and Performance of Malaysian Companies. Managerial Auditing Journal, vol. 23(8), 744-778.

19. S. S. Chen, and K. W. Ho, "Corporate diversification, ownership structure and firm value: the Singapore evidence. International Review of Financial Analysis, vol. 9(3), 2000, pp. 315-326.

20. Cheng, S., Evans III, J. H. and Nagarajan, N. J. (2008). Board Size and Firm Performance: The Moderating Effects of the Market for Corporate Control. Review of Quantitative Finance and Accounting, vol. 31(2), 121-145.

21. Chtourou, S., Bedard, J. and Courteau, L. (2001). Corporate Governance and Earnings Management. Working Paper.

22. Cheung, W. M., Chung, R. and Fung, S. (2015). The Effects of Stock Liquidity on Firm Value and Corporate Governance. Journal of Corporate Finance 35, 211-231.

23. Claessens, S., Djankov, S. and Lang, L. H. P. (2000). The Separation of Ownership and Control in East Asian Corporations. Journal of Financial Economics, vol. 58, 81-112.

24. Collins, D., Reitenga, A. L. and Sanchez, J. M. (2008). The Impact of Accounting Restatements on CFO Turnover and Bonus Compensation: Does Securities Litigation Matter? Advances in Accounting, vol. 24(2), 162-171.

25. Davidson, R., Stewart, J. G. and Kent, P. (2005). Internal Governance Structures and Earnings Management. Accounting \& Finance, vol. 45(2), 241-267.

26. Dechow, P. M., Sloan, R. and Sweeney, A. (1996). Causes and Consequences of Earnings Manipulations: Analysis of Firms Subject to Enforcement Actions by the SEC," Contemporary Accounting Research (Spring), 1-36.

27. DeFond, M. L., Hann, R. N. and Hu, X. (2005). Does the Market Value Financial Expertise on Audit Committees of Boards of Directors? Journal of Accounting Research, vol. 43(2), 153-193.

28. Desai, H., Hogan, C. E. and Wilkins, M. S. (2006). The Reputational Penalty for Aggressive Accounting: Earnings Restatements and Management Turnover. The Accounting Review, vol. 81(1), 83-112.

29. Dey, A., Engel, E. and Liu, X. (2011). CEO and Board Chair Roles: to Split or Not to Split? Journal of Corporate Finance, vol. 17(5), 1595-1618.

30. Doğan, M., Elitaş, B. L., Ağca, V. and Ögel, S. (2013). The Impact of CEO Duality on Firm Performance: Evidence from Turkey. International Journal of Business and Social Science, vol. 4(2), 149-155. 
31. Eisenberg, T., Sundgren, S. and Wells, M. T. (1998). Larger Board Size and Decreasing Firm Value in Small Firms. Journal of Financial Economics, vol. 48(1), 35-54.

32. Fama, E. F. and Jensen, M. C. (1983). Agency Problems and Residual Claims. Journal of Law \& Economics, vol. 26(2), 327-349.

33. Faccio, M. (2006). Politically Connected Firms. The American Economic Review, vol. 96(1), 369-386.

34. Firth, M., Fung, P. M. Y. and Rui, O. M. (2007). Ownership, Two-tier Board Structure, and the Informativeness of Earnings - Evidence from China. Journal of Accounting and Public Policy, vol. 26, 463-496.

35. GAO. (2002). Financial Statement Restatement: Trends, Market Impacts, Regulatory Responses and Remaining Challenges, Report to the Chairman, Committee on Banking, Housing, and Urban Affairs, US Senate, Report 03-138, Government Printing Office, Washington, DC.

36. GAO. (2006). Financial Restatement Database, Report 06-1053R, Government Printing Office, Washington, DC.

37. Ghazali, N. A. M. (2010). Ownership Structure, Corporate Governance and Corporate Performance in Malaysia. International Journal of Commerce and Management, vol. 20(2), 109-119.

38. Gul, F. A. and Leung, S. (2004). Board Leadership, Outside Directors' Expertise and Voluntary Corporate Disclosures. Journal of Accounting and Public Policy, vol. 23(5), 351-379.

39. Haniffa, R. and Hudaib, M. (2006). Corporate Governance Structure and Performance of Malaysian Listed Companies. Journal of Business Finance \& Accounting, vol. 33(7), 1034-1062.

40. Hasnan, S., Abdul Rahman, R. and Mahenthiran, S. (2013). Management Motive, Weak Governance and Fraudulent Financial Reporting: Malaysian Evidence. Journal of International Accounting Research, vol. 12(1), 1-27.

41. Hribar, P. and Jenkins, N. T. (2004). The Effect of Accounting Restatements on Earnings Revision and the Estimated Cost of Capital. Review of Accounting Studies, vol. 9, 337-356.

42. Ibrahim, H. and Samad, F. A. (2011). Corporate Governance Mechanisms and Performance of Public-Listed Family-Ownership in Malaysia. International Journal of Economics and Finance, vol. 3(1), 105-115.

43. Jensen, M. C. and Meckling, W. H. (1976). Theory of the Firm: Managerial Behavior, Agency Costs and Ownership Structure. Journal of Financial Economics, vol. 3(4), 305-360.

44. Jensen, M.C. (1993). The Modern Industrial Revolution, Exit and the Failure of Internal Control Systems. Journal of Finance, vol. 48(3), 831-880.

45. Johnson, S. and Mitton. T. (2003). Cronyism and Capital Controls: Evidence from Malaysia. Journal of Financial Economics, vol. 67, 351-382.

46. Jung, K. and Kwon, S. Y. (2002). Ownership Structure and Earnings Informativeness: Evidence from Korea. The International Journal of Accounting, vol. 37(3), 301-325.

47. Karamanou, I. and Vafeas, N. (2005). The Association between Corporate Boards, Audit Committees and Management Earnings Forecast: An Empirical Analysis. Journal of Accounting Research, vol. 43(3), 453-486.

48. Kryzanowski, K. and Zhang, Y. (2013). Financial Restatements and Sarbanes-Oxley: Impact on Canadian Firm Governance and Management Turnover. Journal of Corporate Finance, vol. 21, 87-105.

49. Kuala Lumpur Stock Exchange (KLSE), (2001). Listing Requirements of Bursa Malaysia Securities Berhad for the MESDAQ Market, Malaysia. $\quad$ Available: http://www.tehlee.com.my/updates/Listing_Requirement_Mesdaq.pdf.

50. Levitt, A. (2000). Speech by SEC Chairman: Renewing the Covenant with Investors. U.S. Securities and Exchange Commission, New York University. Center for Law and Business.

51. Lin, Y. F. (2005). Corporate Governance, Leadership Structure and CEO Compensation: Evidence from Taiwan. Corporate Governance: An International Review, vol. 13(6), 824-835.

52. Lipton, M. and Lorsch, J. (1992). A Modest Proposal for Improved Corporate Governance. Business Lawyer, vol. 48(1), 59-78.

53. Ma, C. (2011). Research on Impact of Financial Restatement on Firm Value in Chinese Listed Firms, Available: http://papers.ssrn.com/sol3/papers.cfm?abstract_id=1870971.

54. Mak, Y. T. and Kusnadi, Y. (2005). Size Really Matters: Further Evidence on the Negative Relationship between Board Size and Firm Value. Pacific-Basin Finance Journal, vol. 13(3), 301-318.

55. Maury, B. (2006). Family Ownership and Firm Performance: Empirical Evidence from Western European Corporations. Journal of Corporate Finance, vol. 12(2), 321-341.

56. McMullen, D. and Raghunanthan, K. (1996). Enhancing Audit Committee Effectiveness. Journal of Accountancy, vol. 182, 79-81.
57. Mitra, S. and Cready, W. M. (2005). Institutional Stock Ownership, Accrual Management and Information Environment. Journal of Accounting, Auditing \& Finance, vol. 20(3), 257-286.

58. Palmrose, Z. V. Richardson, V. J. and Scholz, S. (2004). Determinants of Market Reactions to Restatement Announcements. Journal of Accounting and Economics, vol. 37(1), 59-89.

59. Pfeffer, J. (1972). Size and Composition of Corporate Board of Directors. Administrative Science Quarterly, vol. 21, 218-228.

60. Pillania, R. K., Ogbechie, C. Koufopoulos D. N. and Argyropoulou, M. (2009). Board Characteristics and Involvement in Strategic Decision Making. Management Research News.

61. Rotenstein, A. (2008). Corporate Governance Changes following Earnings Restatements. ProQuest, Unpublished $\mathrm{PhD}$ dissertation, the City University of New York.

62. Shanthikumar, D. M. (2012). Consecutive Earnings Surprises: Small and Large Trader Reactions. The Accounting Review, vol. 87(5), 1709-1736.

63. Shleifer, A. and Vishny, R. W. (1997). A Survey of Corporate Governance. Journal of Finance, vol. 52 (June), 737-783.

64. Srinivasan, S. (2005). Consequences of Financial Reporting Failure for Outside Directors: Evidence from Accounting Restatements and Audit Committee Members. Journal of Accounting Research, vol. 43(2), 291-334.

65. Wang, X. and Wu, M. (2011). The Quality of Financial Reporting in China: An Examination from an Accounting Restatement Perspective. China Journal of Accounting Research, vol. 4(4), 167-196.

66. Wu, W., Wu, C. and Rui, O. M. (2012). Ownership and the Value of Political Connections: Evidence from China. European Financial Management, vol. 18(4), 695-729.

67. Xie, B., Davidson, W. N. and DaDalt, P. J. (2003). Earnings Management and Corporate Governance: The Role of the Board and the Audit Committee. Journal of Corporate Finance, vol. 9(3), 295-316.

68. Zahra, S. A and Pearce, J. A. (1989). Boards of Directors and Corporate Financial Performance: A Review and Integrative Model. Journal of Management, vol. 15(2), 291-334. 